\title{
Using System Dynamics to Model the Transition to Biofuels in the United States
}

Conference Paper NREL/CP-150-43153 June 2008

\section{Preprint}

B. Bush, M. Duffy, and D. Sandor

National Renewable Energy Laboratory

S. Peterson

Peterson Group

To be presented at the Third International Conference on Systems of Systems Engineering Monterey, California June 2-4, 2008 


\section{NOTICE}

The submitted manuscript has been offered by an employee of the Midwest Research Institute (MRI), a contractor of the US Government under Contract No. DE-AC36-99G010337. Accordingly, the US Government and MRI retain a nonexclusive royalty-free license to publish or reproduce the published form of this contribution, or allow others to do so, for US Government purposes.

This report was prepared as an account of work sponsored by an agency of the United States government. Neither the United States government nor any agency thereof, nor any of their employees, makes any warranty, express or implied, or assumes any legal liability or responsibility for the accuracy, completeness, or usefulness of any information, apparatus, product, or process disclosed, or represents that its use would not infringe privately owned rights. Reference herein to any specific commercial product, process, or service by trade name, trademark, manufacturer, or otherwise does not necessarily constitute or imply its endorsement, recommendation, or favoring by the United States government or any agency thereof. The views and opinions of authors expressed herein do not necessarily state or reflect those of the United States government or any agency thereof.

Available electronically at http://www.osti.gov/bridge

Available for a processing fee to U.S. Department of Energy and its contractors, in paper, from:

U.S. Department of Energy

Office of Scientific and Technical Information

P.O. Box 62

Oak Ridge, TN 37831-0062

phone: 865.576 .8401

fax: 865.576 .5728

email: mailto:reports@adonis.osti.gov

Available for sale to the public, in paper, from:

U.S. Department of Commerce

National Technical Information Service

5285 Port Royal Road

Springfield, VA 22161

phone: 800.553 .6847

fax: 703.605.6900

email: orders@ntis.fedworld.gov

online ordering: http://www.ntis.gov/ordering.htm 


\section{Using System Dynamics to Model the Transition to Biofuels in the United States}

\author{
Brian Bush, Michael Duffy, and Debra Sandor \\ National Renewable Energy Laboratory \\ Golden, CO, U.S.A. \\ brian_bush,michael_duffy,debra_sandor@nrel.gov
}

\author{
Steve Peterson \\ Peterson Group \\ Lebanon, NH, U.S.A. \\ steve@evans-peterson.com
}

\begin{abstract}
Today, the U.S. consumes almost 21 million barrels of crude oil per day; approximately $60 \%$ of the U.S. demand is supplied by imports. The transportation sector alone accounts for two-thirds of U.S. petroleum use. Biofuels, liquid fuels produced from domestically-grown biomass, have the potential to displace about $30 \%$ of current U.S. gasoline consumption. Transitioning to a biofuels industry on this scale will require the creation of a robust biomass-to-biofuels system-of-systems that operates in concert with the existing agriculture, forestry, energy, and transportation markets. The U.S. Department of Energy is employing a system dynamics approach to investigate potential market penetration scenarios for cellulosic ethanol, and to aid decision makers in focusing government actions on the areas with greatest potential to accelerate the deployment of biofuels and ultimately reduce the nation's dependence on imported oil.
\end{abstract}

Keywords: system dynamics, biofuels, biomass, renewable, energy, system of systems, modeling, simulation.

\section{Introduction \& Background}

Ready access to affordable oil has been a cornerstone of the U.S. economy for decades. Today, the U.S. consumes almost 21 million barrels of crude oil and refined products per day - almost one-quarter of the world's total crude oil consumption of 85 million barrels per day. Approximately $60 \%$ of the current U.S. demand is supplied by imports [1]. The transportation sector, which receives nearly all of its energy from petroleum products, accounts for two-thirds of U.S. petroleum use.

In the past few years, world oil prices have increased significantly-from a range of $\$ 15-25$ per barrel range during the mid-1980s until 2002 to over $\$ 100$ per barrel in early 2008. The underlying drivers, such as low spare world-oil-production capacity and rapid world oil demand growth, are expected to continue to impact the world oil market for the foreseeable future. The jump in oil prices has spurred a flurry of investment in biofuels (specifically ethanol) by venture capitalists, Wall Street investors, farmers, and automakers. The federal government has also stepped up its efforts; most recently, President Bush signed the Energy Independence and Security Act (EISA) [2], implementing his "Twenty in Ten" goal to cut U.S. gasoline consumption by $20 \%$ over the next 10 years that focuses on two key elements:

- A renewable fuels standard (RFS) requiring fuel producers to use at least 36 billion gallons of biofuels in 2022 (16 billion gallons of cellulosic biofuels) ( $\sim 15 \%$ reduction)

- A national fuel economy standard of 35 miles per gallon by 2020 ( $\sim 5 \%$ reduction)

The U.S. Department of Energy (DOE) Office of the Biomass Program (OBP) has been tasked with leading the effort to meet the cellulosic biofuels mandate of EISA. Transitioning from our current petroleum-based transportation fuel economy to a future fuel economy that incorporates significant amounts of alternative and renewable transportation fuels can be characterized and addressed as a System of Systems (SoS) problem. This paper describes how system dynamics can be employed to understand possible sequences of events behind the deployment of biofuels technology and, ultimately, to guide the transition to a biomass-to-biofuels SoS.

Recent controversy over the possible greenhouse gas emissions side effects of land-use change associated with increased biofuels production [3] [4] further highlights the value of comprehensive SoS modeling of the full biofuels supply chain along with its coupling to the broader agriculture, economic, and energy systems.

\section{System of Systems}

\subsection{Overview}

SoS is an emerging capability- or enterprise-based approach to solving complex problems in which multiple complex systems interact both independently and as an integrated whole. While SoS has its roots in the established systems engineering discipline, as outlined in Table 1, addressing $\mathrm{SoS}$ goes beyond traditional systems engineering in a number of ways. This broader, more flexible approach of SoS Engineering (SoSE) is needed to characterize the complexity of an evolving and expanding biomass-to-biofuels SoS. 
Table 1. Differences between Traditional Systems Engineering and SoSE [5]

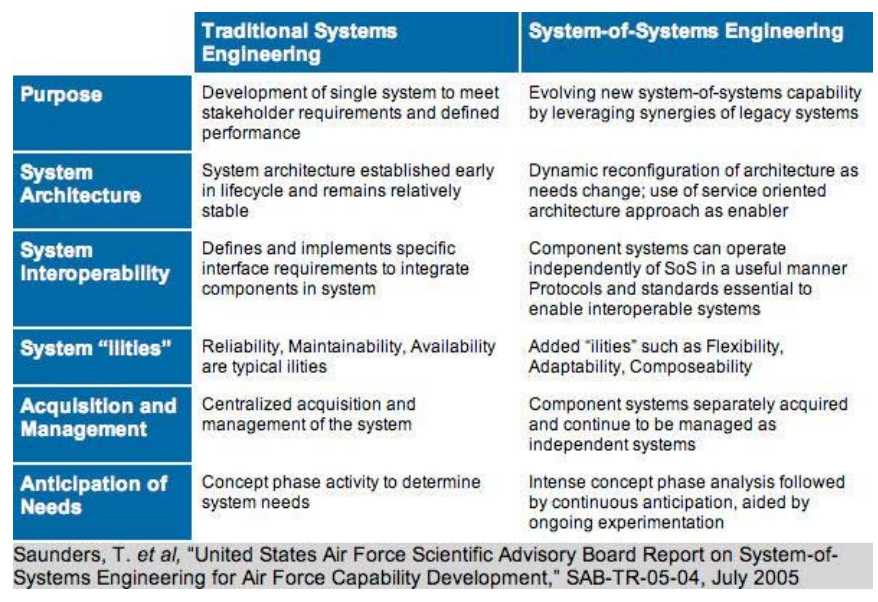

\subsection{System of Systems as a Framework for Biofuels Deployment}

Deploying large volumes of cellulosic ethanol to meet the EISA mandate will require significant technology advancements in concert with effective government policies to motivate industry transformation across the biomass-tobiofuels supply chain. The existing petroleum-based, feedstock-to-fuel supply chain is a decades-old, fully mature, highly networked, and relatively efficient SoS. As such, it contains great inertia-resulting from sunk costs in the current infrastructure and consumer expectations regarding performance, cost and safety-that will influence the energy economy well into the future. Transitioning to a biofuels SoS will require initially integrating with and ultimately transforming industries of the current transportation fuel SoS supply chain-i.e., petroleum fuels production and distribution industries and the automobile industry as well as the well-established industries that will provide biomass feedstock (e.g., agricultural, forestry, waste management) and produce biofuels (e.g., corn ethanol industry).

While the OBP can identify and direct the research and development (R\&D) required to meet the advanced technology requirements and provide cost-share funds to prove integrated technologies in demonstration-scale plants, the full-scale infrastructure development and technology commercialization will be done by industry (from shifting agricultural land use, to building capital-intensive biorefineries, to establishing the infrastructure and public vehicle fleet for ethanol distribution and end use). Contributing to the President's goals will require the focused, coordinated and collaborative action of a multitude of diverse stakeholders. The many stakeholders with key roles in the development of the future biomass-tobiofuels SoS are shown in Figure 1.

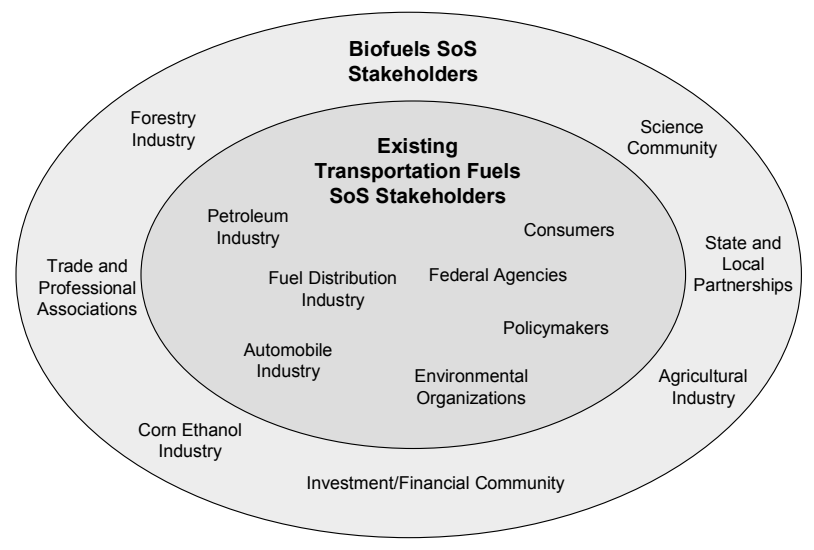

Figure 1. Stakeholders in a future biomass-to-biofuels SoS.

To align and coordinate all of these stakeholders' efforts, OBP has organized its efforts across the biomassto-biofuels supply chain, which can be viewed as a system of five major systems from the farmer's field to the consumer's vehicle, as illustrated in Figure 2. This system of systems framework creates the potential to analyze and understand the workings of individual systems, in isolation and in concert, as the industry evolves over time.

\section{System Dynamics Approach}

\subsection{Overview}

To represent and simulate the behavior of this SoS, we
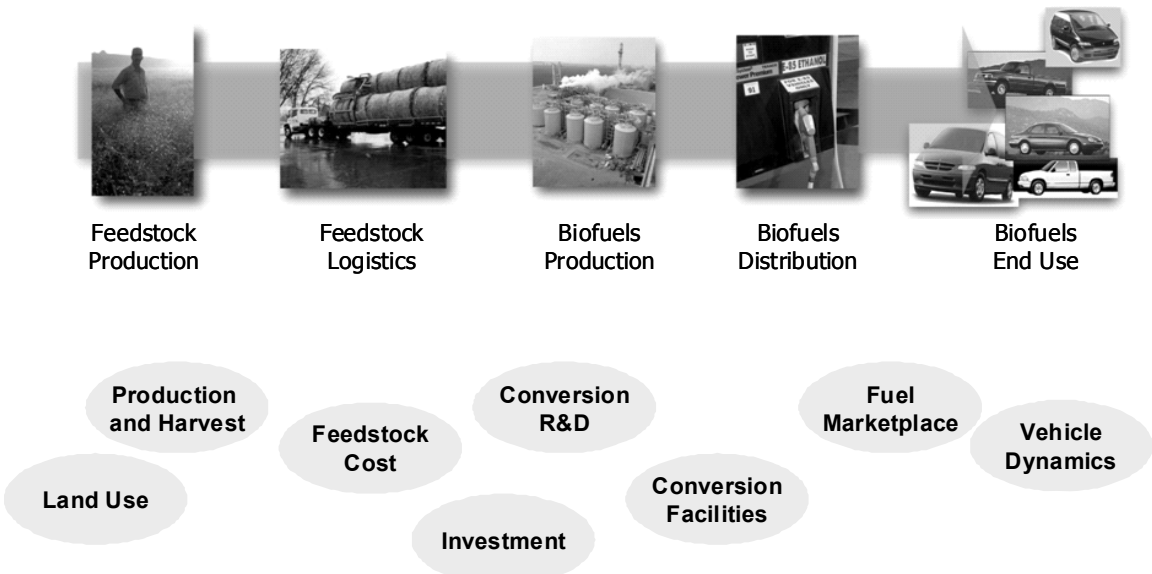

Figure 2. The biomass-to-biofuels supply chain: a system of five systems (top) and concerns within those (bottom). 
have adopted a system dynamics approach. System dynamics originated at the Massachusetts Institute of Technology in the 1950s as a tool to improve understanding of complex industrial processes. Since then system dynamics has been productively applied to a wide range of industrial and organizational, and policy-oriented systems problems [6]. Effective system dynamic applications represent real-world systems using stocks and flows to capture essential accumulations and activities. Drivers of activity within the system are represented as informationfeedback processes. The resultant model of the feedback structure constitutes a theory of system structure which is closely tied to system performance.

SoS problems tend to share four important characteristics:

- They involve dynamics - change over time is a defining characteristic of the issue-space

- Multiple players and diverse interests interact to impact system performance

- Interdependencies among different systems and processes are critical to overall SoS performance

- Communication of issues, structure, and leverage points can be very difficult.

Using these criteria as a filter, the potential evolutionary trajectories of a biofuels industry in the United States can be seen as a classic system dynamics problem. The issues involve dynamics around developing, transitioning, and sustaining an entire industry. Multiple players are involved-ranging from farmers to venture capitalists to automobile manufacturers to congressional policy makers. Failure to understand and develop any link within the supply chain can thwart development of the industry. And finally, because both detail and dynamic complexity is so rich, it can be very difficult to understand and communicate the SoS interactions from the perspective of a single disciplinary framework.

A system dynamics model of the biofuels industry thus has potential to improve understanding of system behavior, to provide useful inputs to the policy evaluation process, and to serve as a vehicle for evaluating alternative policy actions. In contrast to simply forecasting future events, system dynamic models attempt to identify the underlying structure in order to show how to steer, control, or otherwise influence the future evolution of the system.

\subsection{OBP's System Dynamics Model}

\subsubsection{Biomass Scenario Model Overview}

The Biomass Scenario Model (BSM) was developed to investigate the dynamics associated with the potential evolutionary trajectories of a biofuels industry in the U.S.
The model uses a system dynamics framework, built on the STELLA software platform [7], to represent the dynamic interactions of the major systems that comprise the envisioned biomass-to-biofuels SoS. This model tracks the deployment of ethanol given development of new technologies (in feedstock collection, conversion, and vehicles) and the reaction of the investment community to those technologies in light of the competing oil market, vehicle demand for biofuels, and various government policies over time. Its intended use is to generate plausible scenarios around the evolution of an ethanol transportation fuel industry in the U.S. The BSM is currently undergoing significant revision in order to provide a richer view into feedstock production and logistics, conversion technology, fuel infrastructure, and markets.

Although the original prototype of the BSM included only five modules, the new version of the BSM is comprises of seven modules (six representing the biomassto-biofuels supply chain and one representing the existing petroleum industry), which can be run in isolation or in complete or ad hoc combination. As is evident from Figure 3 , each module corresponds to one of the major systems in the biomass-to-biofuels SoS. Each module, in turn, is comprised of several sectors representing separate areas of concern within the system. Thus our architectural approach for the BSM mirrors the real-world hierarchy of interdependent systems that each are composed of interacting subsystems. This decomposition facilitates parallel development, testing, data management, validation, and reviews for the modules and makes the BSM project considerably more agile.

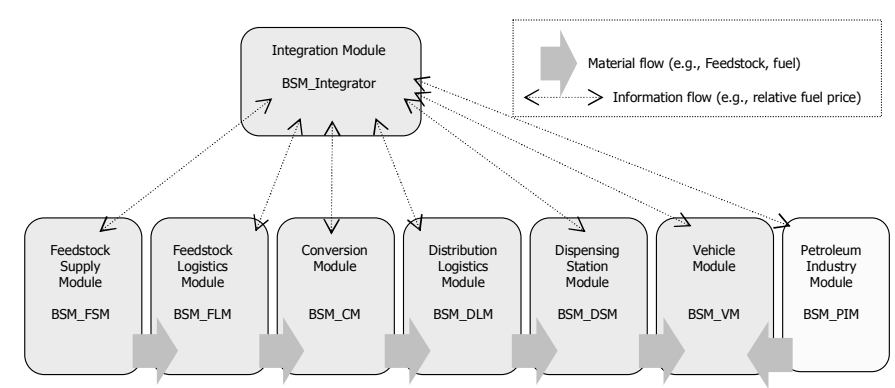

Figure 3. The BSM modules and the module integrator.

The OBP's overarching goal for each system of the supply chain [8] and the objective of the analogous BSM module are summarized in Table 2. A highly simplified representation of key feedbacks captured within the supply chain framework is shown in Figure 4. 


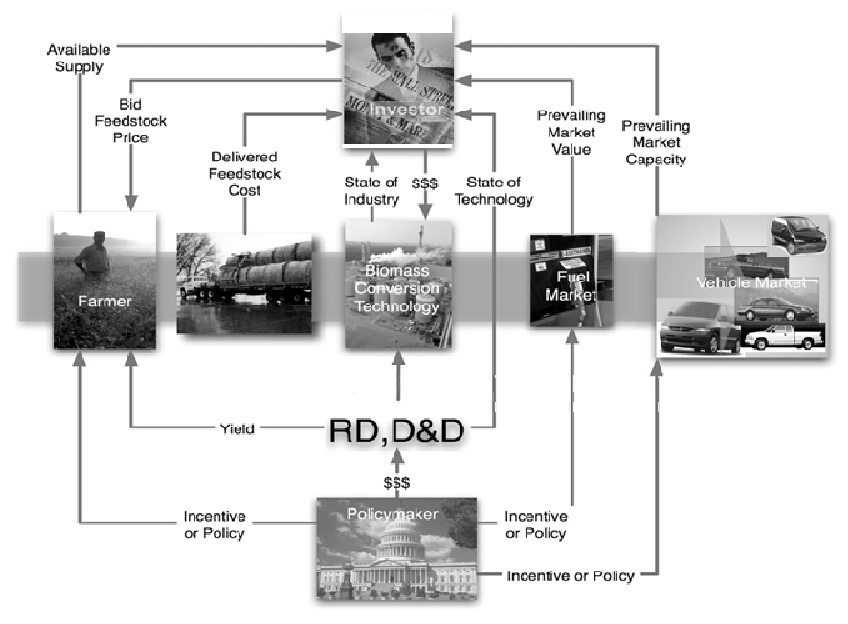

Figure 4. Key feedbacks captured in the BSM.

As suggested in Figure 4, for example, limited availability of feedstock can constrain the rate of growth in cellulosic ethanol production capacity. Meanwhile, mismatches between available supply and quantity demanded at a given price will tend to drive changes in price.

In the current BSM, the dynamics of the growth across the supply chain are determined by the timing of the build up of the infrastructure associated with each system. From a SoS perspective, this build up of the supply chain infrastructure is the capability that must be deployed to realize a future biofuels industry. This capability is developed in the context of the competing oil market, vehicle demand for biofuels and various government policies over time. In the model, the build up of the infrastructure is determined by the dynamics of investor decisions. Investor response is driven by the performance and cost competitiveness of the fuels (which are driven by technology advancements due to R\&D progress) along with the potential demand for them in the marketplace. Specific government policies and external economic factors (e.g., interest rates, price of gasoline) are evaluated as to their impact on the relative attractiveness of investing in new biofuels technology. Data for the model is derived from more detailed and narrowly-focused studies of individual systems of the supply chain including feedstock logistics analyses, agricultural economics analyses, process models, life cycle assessment, economic models and market analyses.

The BSM has great potential as a tool for generating and evaluating scenarios and relative impacts of cost targets, policy drivers, tipping points, etc. However, highlevel system models such as the BSM cannot provide absolutes to a high degree of precision (see Table 3). Thus the BSM is best suited for (i) the analysis and evaluation of alternate policies, (ii) scenario generation, (iii) identification of high-impact levers and bottlenecks to system evolution, and (iv) seeding focused discussion among policy makers, analysts, and stakeholders. When the model output reaches unusually dramatic system-behavioral regimes, modeling assumptions-particularly the behavioral aspects of decision making and the adequacy of the representation of feedback-need careful reexamination. The model itself often indicates which assumptions need most scrutiny; hence, it helps define the research and learning agenda.

Table 2. Biomass Program Goals and BSM Objectives by Biomass-to-Biofuels Supply Chain Element

\begin{tabular}{|l|l|l|}
\hline Supply Chain Element & Biomass Program Goal & Current BSM Module Objective \\
\hline Feedstock Production & $\begin{array}{l}\text { Produce large, sustainable supplies of } \\
\text { regionally available biomass }\end{array}$ & $\begin{array}{l}\text { Feedstock Supply Module. Provide a basis for } \\
\text { production of cellulosic feedstocks, respecting } \\
\text { constraints imposed by the agricultural land } \\
\text { base in a manner consistent with economics. }\end{array}$ \\
\hline Feedstock Logistics & $\begin{array}{l}\text { Implement biomass feedstock } \\
\text { infrastructure, equipment, and systems } \\
\text { (biomass harvesting, collection, } \\
\text { preprocessing, storage, and transportation) }\end{array}$ & $\begin{array}{l}\text { Feedstock Logistics Module. Account for cost } \\
\text { associated with moving biomass feedstock } \\
\text { from the point of production (farm gate) to the } \\
\text { point of conversion (plant gate). }\end{array}$ \\
\hline Biofuels Production & $\begin{array}{l}\text { Deploy cost-effective, integrated biomass- } \\
\text { to-biofuels conversion facilities }\end{array}$ & $\begin{array}{l}\text { Conversion Module. Represent biomass-to- } \\
\text { ethanol conversion process and the logic } \\
\text { associated with the decision to add new plant } \\
\text { to the system. }\end{array}$ \\
\hline Biofuels Distribution & $\begin{array}{l}\text { Implement biofuels distribution } \\
\text { infrastructure (storage, blending, } \\
\text { transportation, and dispensing) }\end{array}$ & $\begin{array}{l}\text { Distribution Logistics and Dispensing Station } \\
\text { Modules. In development. (Prototype BSM } \\
\text { assumes that biofuels distribution does not } \\
\text { limit development of the biofuels industry.) }\end{array}$ \\
\hline Biofuels End Use & $\begin{array}{l}\text { Expand public availability of biofuels- } \\
\text { compatible vehicles with same } \\
\text { performance as petroleum fuels }\end{array}$ & $\begin{array}{l}\text { Vehicle Module. Represent the consumption of } \\
\text { fuel ethanol based on the potential demand for } \\
\text { ethanol as E10 and E85 and the impacts of } \\
\text { vehicle mix and efficiency. }\end{array}$ \\
\hline
\end{tabular}


Table 3. Potential Uses of the BSM.

\begin{tabular}{|l|l|}
\hline Appropriate Usage & Inappropriate Usage \\
\hline Generate scenarios to explore future biofuels landscapes. & Generate $x$ gallons in $y$ years with $z$ dollars investment. \\
\hline Identify areas of potential high leverage. & $\begin{array}{l}\text { Identify specific numerical values of particular } \\
\text { investments. }\end{array}$ \\
\hline $\begin{array}{l}\text { Assess relative merits of technologies and logistics in a } \\
\text { gross sense, given solid technological assumptions. }\end{array}$ & Make fine distinctions between potential of technologies. \\
\hline $\begin{array}{l}\text { Explore the potential for tipping-point and lock-in/lock- } \\
\text { out dynamics. }\end{array}$ & $\begin{array}{l}\text { Predict precisely tipping points and pin them to specific } \\
\text { times. }\end{array}$ \\
\hline $\begin{array}{l}\text { Build intuition, insight, and knowledge around the } \\
\text { supply chain. }\end{array}$ & Use as a definitive embodiment of knowledge. \\
\hline $\begin{array}{l}\text { Think through the relative efficacy of different policy } \\
\text { prescriptions. }\end{array}$ & Rely solely on it to define policy. \\
\hline
\end{tabular}

\subsubsection{Preliminary Results \& Policy Insights}

The current version of the BSM was recently used to help OBP understand potential growth trajectories and likely volumes of cellulosic ethanol that could be produced as a result of various government initiatives [9]. Specifically, scenarios were developed to compare various government initiatives targeted at reducing operating costs and/or capital cost of cellulosic ethanol production. All options were evaluated in the context of influencing the investment decision to build full-scale cellulosic ethanol production facilities. As shown in Figure 5, the analysis suggests that the policies considered-feedstock grower payment, cellulosic ethanol production subsidy, and capital subsidy for construction of full-scale cellulosic ethanol production facilities - can motivate increased production of cellulosic ethanol production by 2017 .

Latent within the BSM are positive feedbacks that in isolation would tend to underwrite exponential growth in cellulosic production capacity (as indicated by the nonlinearity of the curves in Figure 5). The rate of growth in the industry can be constrained by investment risk as well as operating costs. By ameliorating these constraints to varying degrees, the scenario policy initiatives enable growth in production relative to the Base Case. These results suggest that government initiatives can be used to "prime the pump," reducing investment risk and initial operating cost, thus enabling the new industry to grow to the point at which it has become self-sustaining.

\subsection{Conclusions and Next Steps}

A significant shift in the transportation energy sector is on the horizon as oil supplies tighten and the growth in worldwide energy demand accelerates. Increased pressure for environmentally and economically sustainable technologies and concerns about national energy security will also shape our future transportation systems. A SoS framework can effectively guide this complex evolutionary

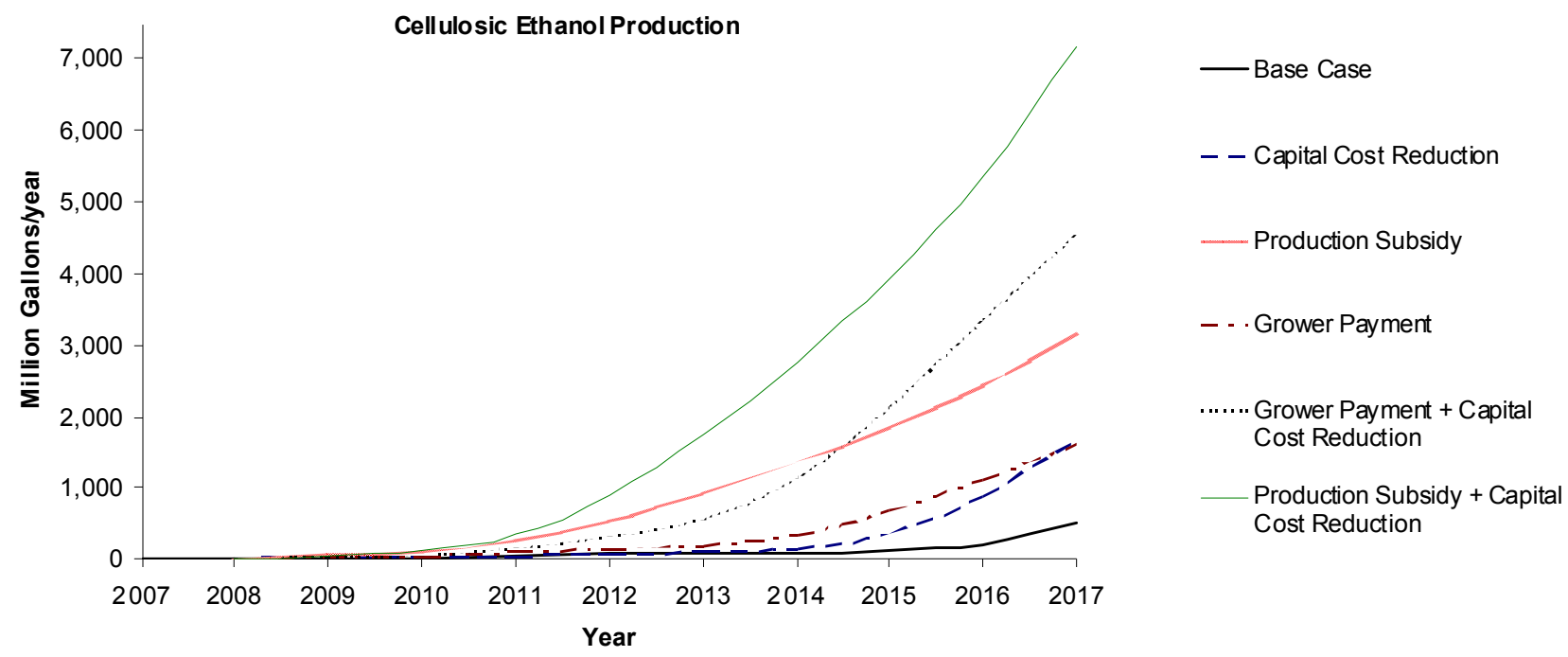

Figure 5. Cellulosic Ethanol Production: Base Case and Five Scenarios 
process in which advanced energy technologies and systems will be continually integrated into the existing transportation fuel infrastructure as they become commercially available.

Scenarios evaluated in the system dynamics-based BSM help policy makers to envision, in broad terms, the emergence of a sustainable biomass-based industry and plausible future conditions. Its relatively intuitive nature is well suited to the "what if" scenario building needed to understand the possible paths for a new biomass-to-biofuels SoS. The power of the model is not primarily in the specific numbers it generates, but rather in the insight it provides into how specific actions facilitate or impede the take-off of a biomass-based transportation fuel industry.

Incorporating additional aspects of the "real-world" operational context into the model will lead to a more robust characterization and improved understanding of the full impacts of transitioning to a biomass-to-biofuels SoS. These include:

- Environmental Context: Key environmental issues associated with the biomass-to-biofuels system include soil sustainability, water impacts of feedstock production and conversion processes, and greenhouse gas emissions.

- Social Context: The success of the transition to a biomass-to-biofuels SoS is linked to society's willingness to change-e.g., farmers must switch from cash crops to energy crops and consumers must select alternative vehicles over conventional vehicles.

\section{References}

[1] “Annual Energy Outlook 2008," U.S. Energy Information Administration online, http:/www.eia.doe.gov/ oiaf/aeo/index.html. Accessed April 22, 2008.

[2] "Fact Sheet: Energy Independence and Security Act of 2007," The Whitehouse online, http://www.whitehouse.gov /news/releases/2007/12/20071219-1.html. Accessed April 22, 2008.

[3] Searchinger, T.; Heimlich, R.; Houghton, R.A.; Dong, F.; Elobeid, A.; Fabiosa, J.; Tokgoz, S.; Hayes, D; Yu, T.; (2008). "Use of U.S. Croplands for Biofuels Increases Greenhouse Gases Through Emissions from Land Use Change," Science Magazine online, http://www.sciencemag.org/cgi/content/abstract/1151861. Accessed April 22, 2008.

[4] Wang, M.; Haq, Z. "Response to February 7, 2008 Sciencexpress Article," http://www.transportation.anl.gov/ media_center/news_stories/20080214_response.html.

Accessed April 8, 2008.
[5] Sanders, T., et al. "United States Air Force Scientific Advisory Board Report on Systems-of-Systems Engineering for Air Force Capability Development." SAB TR-05-04, July 2005 http://handle.dtic.mil/100.2/ADA442612. (Table excerpt from System of Systems Engineering Center of Excellence. http://www.sosece.org/index.cfm?fuseaction=79B5908B802C-E84F-655D66D5E5B166F0).

[6] Sterman, John D. Business Dynamics: Systems Thinking and Modeling for a Complex World, Boston: McGraw Hill, 2000.

[7] The ISEE Systems Home Page, 2007. http://www.iseesystems.com/. Accessed April 12, 2008.

[8] Biomass Multi-Year Program Plan. (November 2007). Office of the Biomass Program, Office of Energy Efficiency and Renewable Energy, U.S. Department of Energy.

http://www1.eere.energy.gov/biomass/pdfs/biomass_progra m_mypp.pdf.

[9] Sandor, D.; Wallace, R.; Peterson, S. Understanding the Growth of the Cellulosic Ethanol Industry. NREL TP150-42120. National Renewable Energy Laboratory, 2008. http://www.nrel.gov/docs/fy08osti/42120.pdf. 


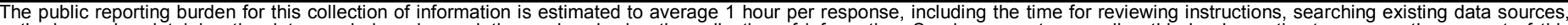

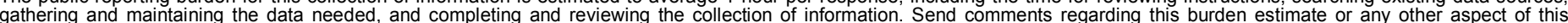

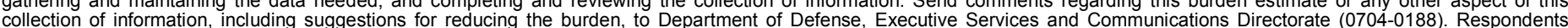

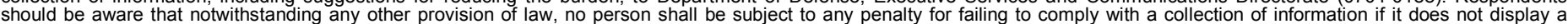

should be aware that notwithstandin

PLEASE DO NOT RETURN YOUR FORM TO THE ABOVE ORGANIZATION.

\begin{tabular}{l|l|l|l} 
1. REPORT DATE $(D D-M M-Y Y Y Y)$ & 2. & REPORT TYPE & 3. DATES COVERED (FrOm - TO)
\end{tabular}

June 2008

Conference paper

4. TITLE AND SUBTITLE

Using System Dynamics to Model the Transition to Biofuels in the

United States: Preprint 5a. CONTRACT NUMBER

DE-AC36-99-G010337

5b. GRANT NUMBER

5c. PROGRAM ELEMENT NUMBER

5d. PROJECT NUMBER

NREL/CP-150-43153

5e. TASK NUMBER

BZ071005

5f. WORK UNIT NUMBER
7. PERFORMING ORGANIZATION NAME(S) AND ADDRESS(ES)

National Renewable Energy Laboratory

1617 Cole Blvd.

Golden, CO 80401-3393
8. PERFORMING ORGANIZATION REPORT NUMBER

NREL/CP-150-43153

9. SPONSORING/MONITORING AGENCY NAME(S) AND ADDRESS(ES)

10. SPONSOR/MONITOR'S ACRONYM(S)

NREL

11. SPONSORING/MONITORING AGENCY REPORT NUMBER

12. DISTRIBUTION AVAILABILITY STATEMENT

National Technical Information Service

U.S. Department of Commerce

5285 Port Royal Road

Springfield, VA 22161

13. SUPPLEMENTARY NOTES

14. ABSTRACT (Maximum 200 Words)

Biofuels, liquid fuels produced from domestically grown biomass, have the potential to displace about $30 \%$ of current U.S. gasoline consumption. Transitioning to a biofuels industry on this scale will require a robust biomass-to-biofuels system-of-systems that operates in concert with the existing agriculture, forestry, energy, and transportation markets. The U.S. Department of Energy is employing a system dynamics approach to investigate potential market penetration scenarios for cellulosic ethanol and to aid decision makers in focusing government actions on the areas with greatest potential to accelerate the deployment of biofuels and ultimately reduce the nation's dependence on imported oil.

15. SUBJECT TERMS

system dynamics; biofuels; biomass; renewable energy; system of systems; modeling; simulation.

\begin{tabular}{l}
\hline \multicolumn{3}{|l|}{ 16. SECURITY CLASSIFICATION OF: } \\
\hline \begin{tabular}{l|l|l|} 
a. REPORT & b. ABSTRACT & c. THIS PAGE \\
Unclassified & Unclassified & Unclassified \\
& & \\
\hline
\end{tabular} \\
\hline
\end{tabular}

\begin{tabular}{l|l} 
17. & LIMITATION \\
OF ABSTRACT & $\begin{array}{l}\text { 18. } \\
\text { NUMBER } \\
\text { OF PAGES }\end{array}$ \\
& \\
\hline
\end{tabular}

19a. NAME OF RESPONSIBLE PERSON

19b. TELEPHONE NUMBER (Include area code) 